\title{
Production, Composition, Fatty Acids Profile and Stability of Milk and Blood Composition of Dairy Cows Fed High Polyunsaturated Fatty Acids Diets and Sticky Coffee Hull
}

\author{
Geraldo Tadeu dos Santos ${ }^{*}$, Ana Luiza Bachmann Schogor ${ }^{1}$, Jakeline Vieira Romero ${ }^{1}$, \\ Luciano Soares de Lima ${ }^{1}$, Paula Toshimi Matumoto-Pintro ${ }^{2}$, Paula Adriana Grande ${ }^{1}$, \\ Daniele Cristina da Silva Kazama ${ }^{1}$ and Fabio Seiji dos Santos ${ }^{1}$ \\ ${ }^{1}$ Departamento de Zootecnia; Universidade Estadual de Maringá; Maringá - PR - Brasil. ${ }^{2}$ Departamento de \\ Agronomia; Universidade Estadual de Maringá; Maringá - PR - Brasil
}

\begin{abstract}
Four lactating Holstein cows were assigned to a $4 \times 4$ Latin square design to determine the effects of feeding sticky coffee hull (SCH) as a source of antioxidants on dairy cows fed with high PUFA diets. The treatments (on DM basis) were control diet, diet with $30 \mathrm{~g} / \mathrm{kg}$ of soybean oil, diet with $30 \mathrm{~g} / \mathrm{kg}$ of soybean oil and $100 \mathrm{~g} / \mathrm{kg}$ of SCH, and diet with $30 \mathrm{~g} / \mathrm{kg}$ of soybean oil and $150 \mathrm{~g} / \mathrm{kg}$ of SCH. Inclusion of $150 \mathrm{~g} / \mathrm{kg}$ of SCH decreased the crude protein digestibility. Lower values of NDF digestibility were also observed when cows were fed with $100 \mathrm{~g} / \mathrm{kg}$ and $150 \mathrm{~g} / \mathrm{kg}$ of SCH. The digestibility of NDT was lower in the control and $150 \mathrm{~g} / \mathrm{kg}$ of SCH diets. Milk production and composition did not differ among the treatments. Inclusion of SCH increased the total polyphenols and flavonoids in the milk and reducing power as well. Soybean oil and SCH supplementation increased the LDL and total cholesterol concentration in the plasma. Milk fatty acid profile was barely altered by the treatments. In conclusion, the results confirmed that SCH added up to $15 \%$ in the diet did not alter milk production, improved its stability, and incorporated antioxidants substances in the milk, improving its quality for human health.
\end{abstract}

Key words: by-product, Coffea arabica, digestibility, flavonoids, milk stability, polyphenols

\section{INTRODUCTION}

Supplemental fat in the diets has become a standard practice to meet the energy requirements of dairy cows. There is growing interest to manipulate the dairy cow diets to increase the polyunsaturated fatty acids (PUFA) content in the milk fat and to improve its nutritional quality. However, fatty acids, especially PUFA, are easily oxidized (Shiota et al. 1999) and may become more susceptible to oxidative damages. In this context, feeding cows with elevated dietary antioxidants may be interesting to increase these compounds in the milk to protect PUFA from oxidation. Additionally, increased antioxidants in the milk may provide several health benefits to the consumers, including protection against free radicals, which are able to oxidize biomolecules, leading to mutagenic changes, tissue damage and cell death (Yang et al. 2000).

The availability of plant phenolic compounds and their effects on human health has been studied due to their antioxidant activity (Korkina 2007; Dai and Mumper 2010). These molecules are also investigated in animal nutrition in order to improve the nutritional value of products, such as

*Author for correspondence: gtsantos@pq.cnpq.br 
milk (Gagnon et al. 2009; Côrtes et al. 2012). Accordingly, finding feedstuffs, which are rich in antioxidant compounds can be a strategy to improve the milk quality.

The processing of coffee, one of the most popular and widely consumed beverages throughout the world (Yen et al. 2005), generates by-products, which are rich in functional compounds, such as phenol acids (Yen et al. 2005; Baggio et al. 2007). Brazil is the largest producer of coffee, thus, generates large amounts of coffee by-products, such as coffee hull. Coffee hull has been used as an alternative feed to the animals due to its high availability $(40 \%$ of total coffee production; Poveda Parra et al. 2008) and low costs. Dry or sticky coffee hull can be obtained, depending on the industrial process. The sticky coffee hull, obtained from dry method, is composed of pith and epicarp, without endocarp, and compared to dry coffee hull it has higher protein and lower NDF and ADF concentration (Vilela et al. 2001).

Both, dry and sticky coffee hull are used to feed the animals. Studies have shown that dry coffee hull could replace both roughage and concentrate feeds, although not recommended in large amount. Souza et al. (2005) reported that dry coffee hull could replace corn $(10.5 \mathrm{~g} / \mathrm{kg} \mathrm{DM})$ in the diets of lactating cows without changing milk production and composition. When used as corn silage substitute, dry coffee hull replaced $12 \%$ (Rocha et al. 2006a) and 14\% (Teixeira et al. 2007) the corn silage in the diets of lactating cows and dairy heifers, respectively. Although coffee hull has been studied as an alternative energy feed, studies on its antioxidant properties are still needed, due to its bioactive compounds content. Therefore, the objective of this trial was to evaluate the effects of sticky coffee hull as natural antioxidant source on the performance and milk quality of dairy cows fed high PUFA diets.

\section{MATERIALS AND METHODS}

This experiment was conducted on Fazenda Experimental de Iguatemi, belonging to the Universidade Estadual de Maringá, Southern Brazil. Four multiparous lactating Holstein cows, averaging $75 \pm 12$ days in milk and $563 \pm 28 \mathrm{~kg}$ of BW were used in a $4 \times 4$ Latin-square design over four 21-d periods. The treatments consisted of four different total mixed diets composed of corn silage, ground corn, soybean meal and mineral supplement as described in Tables 1 and 2.

Table 1 - Chemical composition of ingredients.

\begin{tabular}{|c|c|c|c|c|c|}
\hline \multirow{2}{*}{ Item } & \multicolumn{5}{|c|}{ Ingredients $^{\mathrm{a}}$} \\
\hline & Corn silage & Ground corn & Soybean meal & Sticky coffee hull & Soybean oil \\
\hline Dry matter (g/kg) & 304.3 & 882.2 & 881.5 & 910.0 & 1000 \\
\hline Organic matter ( $\mathrm{g} / \mathrm{kg}$ of $\mathrm{DM})$ & 957.9 & 989.0 & 933.3 & 925.2 & 1000 \\
\hline Crude protein (g/kg of DM) & 70.8 & 84.3 & 506.8 & 94.1 & - \\
\hline $\mathrm{NDICP}^{\mathrm{b}}(\mathrm{g} / \mathrm{kg}$ of CP$)$ & 186.4 & 85.4 & 13.6 & 333.7 & - \\
\hline $\operatorname{ADICP}^{c}(\mathrm{~g} / \mathrm{kg}$ of $\mathrm{CP})$ & 120.1 & 36.8 & 7.5 & 197.7 & - \\
\hline Ether extract (g/kg of DM) & 25.9 & 37.1 & 21.8 & 12.3 & 1000 \\
\hline $\mathrm{NDF}(\mathrm{g} / \mathrm{kg}$ of DM) & 513.4 & 160.1 & 138.6 & 395.0 & - \\
\hline $\begin{array}{l}\text { Non fiber carbohydrates } \\
(\mathrm{g} / \mathrm{kg} \text { of } \mathrm{DM})\end{array}$ & 347.8 & 707.5 & 266.1 & 423.8 & - \\
\hline $\mathrm{ADF}(\mathrm{g} / \mathrm{kg}$ of $\mathrm{DM})$ & 282.5 & 36.7 & 81.5 & 31.91 & - \\
\hline $\operatorname{Lignin}(\mathrm{g} / \mathrm{kg}$ of $\mathrm{DM})$ & 24.9 & 9.0 & 6.7 & 103.7 & - \\
\hline Caffeine $^{\mathrm{d}}(\mathrm{g} / \mathrm{kg}$ of DM) & - & - & - & 5.8 & - \\
\hline Tannins $^{\mathrm{d}}(\mathrm{g} / \mathrm{kg}$ of $\mathrm{DM})$ & - & - & - & 14.4 & - \\
\hline Polyphenols (g GAE/kg of DM) & - & - & - & 7.55 & - \\
\hline Flavonoids (g QE/kg of DM) & - & - & - & 0.50 & - \\
\hline $\mathrm{TDN}_{\text {est }}{ }^{\mathrm{e}}(\mathrm{g} / \mathrm{kg}$ of DM $)$ & 644.0 & 862.4 & 808.4 & 533.9 & 1840 \\
\hline $\mathrm{NE}_{\mathrm{L}}{ }^{\mathrm{e}}(\mathrm{Mcal} / \mathrm{kg}$ of DM $)$ & 1.46 & 1.99 & 1.86 & 1.18 & 5.65 \\
\hline
\end{tabular}

${ }^{\mathrm{a}}$ Mean of 4 pool samples prepared by compositing 7 daily samples collected from d 15 to $21 ;{ }^{b}$ Neutral detergent insoluble crude protein; ${ }^{\mathrm{c}}$ Acid detergent insoluble crude protein; ${ }^{\mathrm{d}}$ Calculated using published values of feed ingredients (Valadares Filho et al. 2013). ${ }^{e}$ Calculated according to NRC (2001). 
Table 2 - Ingredient and chemical composition of total mixed diets of Holstein cows fed no soybean oil and coffee hull (CONT), $30 \mathrm{~g} / \mathrm{kg}$ DM soybean oil (SBOIL), $30 \mathrm{~g} / \mathrm{kg}$ DM soybean oil and $100 \mathrm{~g} / \mathrm{kg}$ of coffee hull (SOCH-100) or $30 \mathrm{~g} / \mathrm{kg}$ DM soybean oil and $150 \mathrm{~g} / \mathrm{kg}$ DM coffee hull (SOCH-150).

\begin{tabular}{|c|c|c|c|c|}
\hline \multirow[b]{2}{*}{ Item } & \multicolumn{4}{|c|}{ Diets } \\
\hline & CONT & SBOIL & SOCH-100 & SOCH-150 \\
\hline \multicolumn{5}{|c|}{ Ingredients $(\mathrm{g} / \mathrm{kg}$ of $\mathrm{DM})$} \\
\hline Corn silage & 600.0 & 600.0 & 500.0 & 450.0 \\
\hline Ground corn & 191.0 & 155.0 & 161.0 & 165.0 \\
\hline Coffee hull & - & - & 100.0 & 150.0 \\
\hline Soybean oil & - & 30.0 & 30.0 & 30.0 \\
\hline Soybean meal & 198.0 & 205.0 & 195.0 & 190.0 \\
\hline Mineral supplement ${ }^{\mathrm{a}}$ & 11.0 & 11.0 & 14.0 & 15.0 \\
\hline \multicolumn{5}{|c|}{ Chemical analysis $^{\mathrm{b}}$} \\
\hline DM $(\mathrm{g} / \mathrm{kg}$ of $\mathrm{NM})$ & 418.4 & 418.3 & 460.7 & 483.7 \\
\hline $\mathrm{OM}(\mathrm{g} / \mathrm{kg}$ of $\mathrm{DM})$ & 949.9 & 948.6 & 943.1 & 941.6 \\
\hline $\mathrm{CP}(\mathrm{g} / \mathrm{kg}$ of $\mathrm{DM})$ & 160.2 & 159.7 & 159.5 & 155.1 \\
\hline $\operatorname{NDICP}(\mathrm{g} / \mathrm{kg}$ of $\mathrm{CP})$ & 66.2 & 65.7 & 77.2 & 85.1 \\
\hline $\mathrm{ADICP}(\mathrm{g} / \mathrm{kg}$ of $\mathrm{CP})$ & 39.9 & 39.8 & 46.1 & 50.6 \\
\hline $\mathrm{EE}(\mathrm{g} / \mathrm{kg}$ of $\mathrm{DM})$ & 27.4 & 57.2 & 58.1 & 55.2 \\
\hline $\mathrm{NDF}(\mathrm{g} / \mathrm{kg}$ of $\mathrm{DM})$ & 365.8 & 361.2 & 340.8 & 332.0 \\
\hline $\mathrm{NFC}(\mathrm{g} / \mathrm{kg}$ of DM) & 396.4 & 370.5 & 387.0 & 399.3 \\
\hline $\mathrm{ADF}(\mathrm{g} / \mathrm{kg}$ of $\mathrm{DM})$ & 192.6 & 191.9 & 195.0 & 203.9 \\
\hline $\operatorname{Lignin}(\mathrm{g} / \mathrm{kg}$ of DM) & 18.0 & 17.7 & 25.6 & 29.1 \\
\hline Caffeine $^{\mathrm{c}}(\mathrm{g} / \mathrm{kg}$ of DM) & - & - & 0.58 & 0.87 \\
\hline Tannins $^{c}(\mathrm{~g} / \mathrm{kg}$ of DM) & - & - & 1.44 & 2.16 \\
\hline $\mathrm{TDN}^{\mathrm{d}}(\mathrm{g} / \mathrm{kg}$ of $\mathrm{DM})$ & 711.2 & 741.0 & 727.1 & 712.1 \\
\hline $\mathrm{NE}_{\mathrm{L}}{ }^{\mathrm{d}}(\mathrm{Mcal} / \mathrm{kg}$ of DM $)$ & 1.62 & 1.70 & 1.66 & 1.62 \\
\hline \multicolumn{5}{|c|}{ Fatty acid, g/100 g of total fatty acid methyl esters } \\
\hline 12:0 & 0.27 & 0.27 & 0.23 & 0.21 \\
\hline $14: 0$ & 0.59 & 0.57 & 0.60 & 0.62 \\
\hline $16: 0$ & 19.38 & 19.30 & 18.62 & 18.28 \\
\hline $16: 1$ & 0.84 & 0.84 & 0.70 & 0.63 \\
\hline 18:0 & 3.71 & 3.68 & 3.61 & 3.57 \\
\hline cis9 18:1 & 25.92 & 25.62 & 25.68 & 25.71 \\
\hline cis7 18:1 & 0.79 & 0.77 & 0.75 & 0.74 \\
\hline cis6 18:2 & 41.51 & 41.82 & 42.22 & 42.42 \\
\hline cis3 18:3 & 5.27 & 5.40 & 5.60 & 5.69 \\
\hline cis3 20:4 & 0.31 & 0.26 & 0.47 & 0.57 \\
\hline $20: 1$ & 0.00 & 0.02 & 0.11 & 0.16 \\
\hline Others & 1.42 & 1.44 & 1.41 & 1.40 \\
\hline PUFA & 47.09 & 47.49 & 48.28 & 48.68 \\
\hline SFA & 23.94 & 23.82 & 23.06 & 22.67 \\
\hline MUFA & 27.55 & 27.25 & 27.24 & 27.25 \\
\hline$n-6^{5}$ & 41.51 & 41.82 & 42.22 & 42.42 \\
\hline$n-3^{6}$ & 5.59 & 5.67 & 6.06 & 6.26 \\
\hline$n-6 / n-3$ & 7.43 & 7.38 & 6.97 & 6.77 \\
\hline
\end{tabular}

${ }^{\mathrm{a}}$ Contained (per kg, as-is basis): Ca 240 g, P 60 g, Mg 15.0 g, S 18.0 g, Na 78.0, Fe 2,200 mg, Zn 3.800 mg, Cu 680 mg, Mn $1.105 \mathrm{mg}$, I $40 \mathrm{mg}$, Co $10 \mathrm{mg}$, Se $25 \mathrm{mg}$, vitamin A 100,000 IU, vitamin D3 66,700 IU, and vitamin E 1,000 IU.

${ }^{\mathrm{b}}$ Mean of 4 pool samples prepared by compositing 7 daily samples collected from d 15 to 21 .

${ }^{c}$ Calculated using published values of feed ingredients (Valadares Filho et al. 2013).

${ }^{\mathrm{d} C}$ Calculated using described equations by NRC(2001).

Non-fiber carbohydrates (NFC) were estimated according to equations described by NRC (2001): $\mathrm{NFC}(\mathrm{g} / \mathrm{kg}$ od DM $)=1000-(\mathrm{CP}+\mathrm{EE}+\mathrm{NDF}+$ ash). The observed total digestible nutrients
$\left(\mathrm{TDN}_{\mathrm{obs}}\right)$ were estimated according to the following equation: $\mathrm{TDN}=\mathrm{dCP}+(2.25 \mathrm{x} \mathrm{dEE})+$ $\mathrm{dNDF}+\mathrm{dNFC}$, where $\mathrm{dCP}=$ digestible crude protein, $\mathrm{dEE}=$ digestible ether extract, $\mathrm{dNDF}=$ 
digestible neutral detergent fiber and $\mathrm{dNFC}=$ digestible nonfiber carbohydrates.

Indigestible NDF (iNDF) was used as an internal marker to estimate the fecal output and apparent nutrient digestibility. For iNDF analysis, $0.5 \mathrm{~g}$ of samples (fecal, refusals and feeds) were grounded to $1 \mathrm{~mm}$ and incubated in situ (144 h) in the rumen of a cow within nylon bags (F57 Ankom), followed by neutral detergent analysis Mertens (2002) by using a Ankom ${ }^{200}$ Fiber Analyzer (Ankom Technology Corp., Fairport, NY).

Milk samples were taken from each cow for four consecutive milkings (d 19 and 20) and pooled on the yield basis to obtain three milk samples per cow. One milk sample was stored at $4^{\circ} \mathrm{C}$ with a preservative (bronopol-B2) until the analysis for protein, urea N, lactose, and total solids. Milk FA profile was determined on the samples pooled on milk yield basis and frozen without preservative at $-20^{\circ} \mathrm{C}$. Another milk sample was kept at $-20^{\circ} \mathrm{C}$ with $\mathrm{Na}$ azide $(0.2 \mathrm{~g} / \mathrm{kg})$ for antioxidants analysis as previously reported by Matumoto-Pintro et al. (2011).

Samples of food, refusals and feces were ovendried $\left(55^{\circ} \mathrm{C}\right.$ for $\left.72 \mathrm{~h}\right)$, grounded $(1 \mathrm{~mm}$ mash) and the dry matter was evaluated according to method no. 934.01 of AOAC (1998). Organic matter was determined by combustion in a muffle furnace according to method no. 942.05 of AOAC (1998). Total nitrogen (TN) was determined using a Tecnal TE-036/1 (Tecnal, Piracicaba, São Paulo, Brazil) following the method no. 988.05 of the AOAC (1998) and crude protein (CP) was estimated as TN $\times$ 6.25. Ether extraction in the diets was conducted with Tecnal TE-044/1 (Tecnal, Piracicaba, São Paulo, Brazil) according to the method no. 920.39 of AOAC (1998). The neutral detergent fiber (NDF) was evaluated as described by (Mertens 2002) using a heat-stable $\alpha$ amylase, without using sodium sulphite. NDF was determined following the Ankom ${ }^{200}$ filter bag technique (Ankom Technology Corp., Fairport, $\mathrm{NY})$. The ADF and lignin content were determined according to AOAC (1998) method no. 973.18. As sequential method, the neutral detergent insoluble crude protein (NDICP) and acid insoluble crude protein (ADICP) were determined as described by Silva and Queiroz (2002).

Protein, lactose, total solids, and urea $\mathrm{N}$ concentrations in the milk samples were analyzed by infrared spectrophotometry (Bentley model 2000; Bentley Instrument Inc., Chaska, MN). Milk somatic cells counts (SCC) were obtained using an electronic counter (Somacount 500, Chaska, MN) as described by Voltolini et al. (2001). Milk fat was obtained by centrifugation as described by Murphy et al. (1995) and FA were methylated according to method 5509 of ISO (1978) using $\mathrm{KOH} /$ methanol (Synth, São Paulo, Brazil) and nheptane (Vetec, Rio de Janeiro, Brazil). Fatty acid methyl esters were quantified by gas chromatography (Trace GC Ultra, Thermo Scientific, EUA) with auto sampler and equipped with a flame-ionization and a Rt-2560 fused-silica capillary column $(100 \mathrm{~m}$ and $0.25 \mathrm{~mm}$ i.d., 0.20 $\mu \mathrm{m}$ film thickness). The column parameters were initial column temperature of $65^{\circ} \mathrm{C}$ for $8 \mathrm{~min}$; the temperature was then programmed at $50^{\circ} \mathrm{C}$ per min to $170^{\circ} \mathrm{C}$. This temperature was maintained for $40 \mathrm{~min}$, then increased $50^{\circ} \mathrm{C}$ per min to $240^{\circ} \mathrm{C}$, and remained at this temperature for $28.5 \mathrm{~min}$. Injector and detector temperatures were 220 and $245^{\circ} \mathrm{C}$, respectively. The gas flow was $1.5 \mathrm{~mL} / \mathrm{min}$ for hydrogen (carrier gas), $30 \mathrm{~mL} / \mathrm{min}$ for nitrogen (auxiliary gas), $35 \mathrm{~mL} / \mathrm{min}$ for hydrogen and 350 $\mathrm{mL} / \mathrm{min}$ for make-up gas (flame gases). Fatty acid peaks were identified using pure methyl ester standards (Sigma, São Paulo, Brazil).

Blood was collected from all the cows on $18 \mathrm{~d}$ after morning milking (08:00h) to determine very low density lipoprotein (VLDL), low density lipoprotein (LDL), high density lipoprotein (HDL), total cholesterol, triacylglycerols, glucose and urea concentrations. Blood was taken from the jugular vein into vacutainer tubes containing heparin. Tubes were immediately centrifuged at $3000 \mathrm{x}$ g for $20 \mathrm{~min}$. Plasma was separated and frozen at $-20^{\circ} \mathrm{C}$ for subsequent analysis. Plasma samples were analyzed using the commercial kits (Diasys ${ }^{\circledR}$ ) in an automatic analyzer (Vitalab Selectra ${ }^{\circledR 2}$ ).

Total polyphenol content in the samples was determined using the Folin-Ciocalteu procedure as described by Singleton and Rossi (1965) and Han et al. (2011), with the following modifications. The polyphenols from sticky coffee hull was dispersed in methanol $(90 \%, \mathrm{v} / \mathrm{v}), 1: 100 \mathrm{~g} / \mathrm{mL}$, and from milk was in methanol $100 \%, 1: 10 \mathrm{~mL} / \mathrm{mL}$ and filtered (PTFE, $0.22 \mu \mathrm{m}$ ). A $0.25 \mathrm{~mL}$ aliquot of samples solution in methanol was mixed with $0.25 \mathrm{~mL}$ Folin-Ciocalteu reagent (previously diluted with water, $1: 1$ ) and $4.50 \mathrm{~mL}$ of a sodium carbonate solution $(28 \mathrm{~g} / \mathrm{L})$. The mixture was left at room temperature in darkness for $30 \mathrm{~min}$ and the absorption was measured at $760 \mathrm{~nm}$ using a UV- 
visible spectrophotometer. A standard curve was prepared using gallic acid and the results were expressed as grams of gallic acid equivalents per kilograms of sticky coffee hull (g GAE/kg) and for milk as $\mu \mathrm{g}$ GAE $/ \mathrm{mL}$.

The flavonoid content of sticky coffee hull and milk was dissolved in methanol (100\%), $0.3 \mathrm{~mL}$ from theses solution were mixed with $0.15 \mathrm{~mL}$ of aluminum chloride $(0,5 \%, \mathrm{w} / \mathrm{v})$ in methanol and $2.25 \mathrm{~mL}$ of methanol (Woisky and Salatino 1998; Sánchez et al. 2010). The mixture was left at room temperature for $30 \mathrm{~min}$ and the absorption was measured at $425 \mathrm{~nm}$ using a UV-visible spectrophotometer. The results were expressed as grams of quercetin equivalent per kilograms of sticky coffee hull (g QE/kg) and $\mu \mathrm{g}$ GAE $/ 100 \mathrm{~mL}$ of the milk.

Total reducing power was determined as described by Zhu et al. (2002) with some modifications. The protein from the milk was precipitated with trichloroacetic acid solution $(20 \% ; \mathrm{w} / \mathrm{v})(1: 1 ; \mathrm{v} / \mathrm{v})$ and the solution was centrifuged $\left(1058 \mathrm{x} \mathrm{g}, 20^{\circ} \mathrm{C}\right)$ for $10 \mathrm{~min}$. A $0.25 \mathrm{~mL}$ aliquot from the supernatant was mixed with $1.25 \mathrm{~mL}$ of phosphate buffer $(0.2 \mathrm{M}, \mathrm{pH} 6.6)$ and $1.25 \mathrm{~mL}$ of potassium ferricyanide $[\mathrm{K} 3 \mathrm{Fe}(\mathrm{CN}) 6](1 \%$ in $\mathrm{HCl}, 10 \mathrm{mM})$. The mixture was then incubated at $50^{\circ} \mathrm{C}$ for 20 min. Afterward, $1.25 \mathrm{~mL}$ of trichloroacetic acid (10\%) was added to the mixture, which was then centrifuged at $1058 \mathrm{x}$ g for $10 \mathrm{~min}$. Finally, $2.5 \mathrm{~mL}$ of the supernatant was mixed with $2.5 \mathrm{~mL}$ of 0.5
$\mathrm{mL} \mathrm{FeCl}_{3}(0.1 \%$ in $\mathrm{HCl} 10 \mathrm{mM})$, and the absorbance was measured at $700 \mathrm{~nm}$ on a UV-Vis spectrophotometer and reducing power was reported as gallic acid equivalents $(\mu \mathrm{g}$ GAE/100 $\mathrm{mL})$.

All the data were analyzed as a $4 \times 4$ Latin square design balanced for residual effect using the MIXED procedure of SAS (2003) with the following model:

$$
\mathrm{Y}_{\mathrm{ijkl}}=\mu+\mathrm{C}_{\mathrm{j}}+\mathrm{P}_{\mathrm{k}}+\mathrm{T}_{\mathrm{l}}+\mathrm{e}_{\mathrm{ijkl}},
$$

where $Y_{i j k l}=$ the dependent variable, $\mu=$ overall mean, $\mathrm{Cj}=$ random effect of cow $(\mathrm{j}=1$ to 4$), \mathrm{P}_{\mathrm{k}}=$ fixed effect of period ( $\mathrm{k}=1$ to 4$), \mathrm{T}_{1}=$ fixed effect of treatment $(1=$ control, soybean oil, oil +100 $\mathrm{g} / \mathrm{kg}$ coffee hull, oil $+150 \mathrm{~g} / \mathrm{kg}$ coffee hull), and $\mathrm{e}_{\mathrm{ijkl}}=$ random residual error. Significance was determined at $\mathrm{P} \leq 0.05$. When a significant F-test was detected, multiple comparisons were done using a Tukey adjustment for the probability.

\section{RESULTS}

Dry matter intake was similar $(\mathrm{P}>0.05)$ among the diets, expressed in $\mathrm{kg} / \mathrm{d}$ and as percentage of body weight (Table 3). The digestibility of dry matter and non-fiber carbohydrates were similar among the diets $(\mathrm{P}>0.05)$. However, crude protein digestibility was reduced in the cows fed $150 \mathrm{~g} / \mathrm{kg}$ of SCH (DM basis), when compared to those fed CON, SBOIL and SOCH-100

Table 3 - Intake, digestibility and total digestible nutrients of Holstein cows fed no soybean oil and coffee hull (CONT), $30 \mathrm{~g} / \mathrm{kg}$ DM soybean oil (SBOIL), $30 \mathrm{~g} / \mathrm{kg}$ DM soybean oil and $100 \mathrm{~g} / \mathrm{kg}$ of coffee hull (SOCH-100) or 30 $\mathrm{g} / \mathrm{kg}$ DM soybean oil and $150 \mathrm{~g} / \mathrm{kg}$ DM coffee hull (SOCH-150).

\begin{tabular}{|c|c|c|c|c|c|c|}
\hline \multicolumn{7}{|c|}{ Diets } \\
\hline Item & CONT & SBOIL & SOCH-100 & SOCH-150 & SE & $P$-value \\
\hline \multicolumn{7}{|c|}{ Intake } \\
\hline $\mathrm{DM}(\mathrm{kg} / \mathrm{d})$ & 19.96 & 18.87 & 19.97 & 18.34 & 0.89 & 0.509 \\
\hline $\mathrm{DM}(\mathrm{g} / \mathrm{kg}$ of $\mathrm{BW})$ & 3.40 & 3.32 & 3.48 & 3.18 & 0.24 & 0.837 \\
\hline \multicolumn{7}{|c|}{ Digestibility $(\mathrm{kg} / \mathrm{kg})$} \\
\hline $\mathrm{DM}$ & 0.691 & 0.691 & 0.702 & 0.665 & 0.011 & 0.219 \\
\hline $\mathrm{CP}$ & $0.709^{\mathrm{a}}$ & $0.714^{\mathrm{a}}$ & $0.718^{\mathrm{a}}$ & $0.651^{\mathrm{b}}$ & 0.010 & 0.005 \\
\hline EE & $0.757^{\mathrm{b}}$ & $0.814^{\mathrm{a}}$ & $0.815^{\mathrm{a}}$ & $0.820^{\mathrm{a}}$ & 0.032 & 0.050 \\
\hline NDF & $0.511^{\mathrm{a}}$ & $0.500^{\mathrm{a}}$ & $0.453^{\mathrm{b}}$ & $0.389^{c}$ & 0.017 & 0.002 \\
\hline NFC & 0.804 & 0.792 & 0.849 & 0.825 & 0.016 & 0.138 \\
\hline \multicolumn{7}{|c|}{ Total digestible nutrients $(\mathrm{g} / \mathrm{kg})$} \\
\hline $\mathrm{TDN}_{\text {observed }}$ & $642.2^{\mathrm{b}}$ & $668.5^{\mathrm{a}}$ & $674.7^{\mathrm{a}}$ & $638.4^{\mathrm{b}}$ & 0.78 & 0.020 \\
\hline
\end{tabular}

${ }^{\mathrm{a}-\mathrm{b}}$ Means within a row with different superscripts differ at $\mathrm{P} \leq 0.05$

The digestibility of EE was increased when soybean oil was added in the diets (SBOIL, SOCH-100 and SOCH-150), compared with the
CONT diet. On the other hand, NDF digestibility decreased when $\mathrm{SCH}$ was added to the diets, presenting lower values for SOCH-150. However, 
the NDF digestibility was better and similar between the CONT and SBOIL diets. The estimated digestibility of TDN presented higher values for SBOIL and SOCH-100 when compared with CONT and SOCH-150 diets, which were similar between each-other.

The milk production (as $\mathrm{kg} / \mathrm{d}$ ) and corrected for $4 \%$ of fat were similar $(\mathrm{P}>0.05)$ among the diets (Table 4). Milk components yields $(\mathrm{kg} / \mathrm{d})$ were also not affected by the treatments, neither SCS. However, when considered in percentage, lactose in milk was reduced when $\mathrm{SCH}$ was supplied to the animals, for both SOCH-100 and SOCH-150 diets when compared with CONT and SBOIL, which were also similar between each-other. Milk urea nitrogen gradually decreased with soybean oil inclusion, decreasing further with $\mathrm{SCH}$ inclusion. The lowest value was observed for SOCH-150 when compared to those fed CONT, SBOIL and SOCH-100 (Table 4). Treatments had no effect on the proportions of protein, fat and total solids in milk. The total polyphenols in the milk increased with $\mathrm{SCH}$ inclusion, presenting higher values when $15 \mathrm{~g} / \mathrm{kg}$ of $\mathrm{SCH}$ were fed to the animals. Similar pattern was observed for flavonoids and reducing power in the milk (Table 4 ).

Table 4 - Milk production, milk composition and blood composition of Holstein cows fed no soybean oil and coffee hull (CONT), $30 \mathrm{~g} / \mathrm{kg}$ DM soybean oil (SBOIL), $30 \mathrm{~g} / \mathrm{kg}$ DM soybean oil and $100 \mathrm{~g} / \mathrm{kg}$ of coffee hull (SOCH-100) or $30 \mathrm{~g} / \mathrm{kg}$ DM soybean oil and $150 \mathrm{~g} / \mathrm{kg}$ DM coffee hull (SOCH-150).

\begin{tabular}{|c|c|c|c|c|c|c|}
\hline \multirow[t]{2}{*}{ Item } & \multicolumn{6}{|c|}{ Diets } \\
\hline & CONT & SBOIL & SOCH-100 & SOCH-150 & SE & $P$-value \\
\hline Milk production $(\mathrm{kg} / \mathrm{d})$ & 26.23 & 28.66 & 29.77 & 26.75 & 2.17 & 0.642 \\
\hline $4 \%$ FCM $(\mathrm{kg} / \mathrm{d})$ & 23.04 & 22.88 & 22.87 & 21.44 & 1.67 & 0.893 \\
\hline \multicolumn{7}{|c|}{ Milk composition (\%) } \\
\hline Protein & 3.08 & 3.06 & 3.12 & 3.09 & 0.18 & 0.998 \\
\hline Fat & 3.36 & 2.68 & 2.57 & 2.97 & 0.35 & 0.421 \\
\hline TS & 11.96 & 11.27 & 10.57 & 10.83 & 0.36 & 0.099 \\
\hline Lactose & $4.58^{\mathrm{a}}$ & $4.59^{\mathrm{a}}$ & $4.20^{\mathrm{b}}$ & $4.10^{\mathrm{b}}$ & 0.09 & 0.005 \\
\hline Urea N (mg/dL) & $14.53^{\mathrm{a}}$ & $12.55^{\mathrm{ab}}$ & $11.28^{\mathrm{b}}$ & $8.71^{\mathrm{c}}$ & 0.62 & 0.001 \\
\hline \multicolumn{7}{|c|}{ Milk yield $(\mathrm{kg} / \mathrm{d})$} \\
\hline Protein & 0.75 & 0.74 & 0.75 & 0.72 & 0.08 & 0.994 \\
\hline Fat & 0.82 & 0.67 & 0.63 & 0.71 & 0.14 & 0.804 \\
\hline TS & 2.93 & 2.75 & 2.57 & 2.55 & 0.37 & 0.877 \\
\hline Lactose & 1.13 & 1.12 & 1.03 & 0.96 & 0.14 & 0.834 \\
\hline SCS $\left(\log _{10} \operatorname{SCS}\right)$ & 2.01 & 2.05 & 1.71 & 2.06 & 0.22 & 0.647 \\
\hline \multicolumn{7}{|c|}{ Milk stability } \\
\hline $\begin{array}{l}\text { Total polyphenols }(\mu \mathrm{g} \\
\text { GAE } / \mathrm{mL})\end{array}$ & $19.83^{\mathrm{c}}$ & $26.00^{\mathrm{c}}$ & $29.41^{\mathrm{b}}$ & $33.02^{\mathrm{a}}$ & 0.906 & $<0.0001$ \\
\hline Flavonoids ( $\mu \mathrm{g} \mathrm{QE} / \mathrm{mL}$ ) & $0.46^{\mathrm{b}}$ & $0.64^{\mathrm{b}}$ & $0.76^{\mathrm{ab}}$ & $0.80^{\mathrm{a}}$ & 0.049 & 0.003 \\
\hline $\begin{array}{l}\text { Reducing power }(\mu \mathrm{g} \\
\text { GAE/mL) }\end{array}$ & $17.95^{\mathrm{b}}$ & $16.84^{\mathrm{b}}$ & $20.28^{\mathrm{ab}}$ & $30.61^{\mathrm{a}}$ & 2.534 & 0.001 \\
\hline \multicolumn{7}{|c|}{ Plasma concentration (mg/dL) } \\
\hline Glucose & 65.00 & 63.50 & 66.25 & 64.00 & 1.36 & 0.532 \\
\hline Triacylglycerol & 8.50 & 11.00 & 10.50 & 11.25 & 1.76 & 0.703 \\
\hline HDL & 70.75 & 90.75 & 92.50 & 87.50 & 6.02 & 0.112 \\
\hline LDL & $44.30^{\mathrm{b}}$ & $76.05^{\mathrm{a}}$ & $79.90^{\mathrm{a}}$ & $69.00^{\mathrm{a}}$ & 7.21 & 0.003 \\
\hline VLDL & 1.70 & 2.20 & 2.10 & 2.25 & 0.35 & 0.701 \\
\hline Total Cholesterol & $116.75^{\mathrm{b}}$ & $169.00^{\mathrm{a}}$ & $174.50^{\mathrm{a}}$ & $158.75^{\mathrm{a}}$ & 12.79 & 0.041 \\
\hline
\end{tabular}

${ }^{\mathrm{a}-\mathrm{c}}$ Means within a row with different superscripts differ at $\mathrm{P} \leq 0.05$.

Cows fed high PUFA diets (SBOIL, SOCH-100 and SOCH-150 diets) showed higher LDL and total cholesterol levels in the plasma than the cows fed CONT diet (Table 4). Glucose, triacylglycerol, HDL and VLDL in plasma were not affected by treatments. In general, the milk fatty acids profile was not modified by the diets (Table 5). Nevertheless, the concentration of cis9-18:1 was lower when cows were fed SBOIL compared with
SOCH-100 and SOCH-150. The soybean oil inclusion led to a decrease in rumenic acid (cis9,trans11-18:2) concentration, since the SBOIL and SOCH-100 decreased this fatty acid in the milk, presenting the lowest value for $\mathrm{SOCH}-$ 100. However, when SOCH-150 was fed, the concentration of rumenic acid was similar to CONT (Table 5). 
Table 5 - Fatty acid profile in milk ( $\mathrm{g} / \mathrm{kg}$ of total fatty acid) of Holstein cows fed no soybean oil and coffee hull (CONT), $30 \mathrm{~g} / \mathrm{kg}$ DM soybean oil (SBOIL), $30 \mathrm{~g} / \mathrm{kg}$ DM soybean oil and $100 \mathrm{~g} / \mathrm{kg}$ of coffee hull (SOCH-100) or 30 $\mathrm{g} / \mathrm{kg}$ DM soybean oil and $150 \mathrm{~g} / \mathrm{kg}$ DM coffee hull (SOCH-150).

\begin{tabular}{|c|c|c|c|c|c|c|}
\hline \multirow[t]{2}{*}{ Item } & \multicolumn{6}{|c|}{ Diets } \\
\hline & CONT & SBOIL & SOCH-100 & SOCH-150 & SE & $P$-value \\
\hline 4:0 & 19.5 & 18.6 & 16.5 & 22.9 & 4.03 & 0.730 \\
\hline $6: 0$ & 19.4 & 22.9 & 14.8 & 21.2 & 3.66 & 0.497 \\
\hline $8: 0$ & 17.5 & 15.3 & 11.1 & 15.1 & 2.34 & 0.354 \\
\hline $10: 0$ & 35.9 & 30.7 & 26.4 & 30.0 & 3.12 & 0.245 \\
\hline 11:0 & 4.8 & 3.9 & 2.3 & 3.7 & 0.87 & 0.259 \\
\hline $12: 0$ & 28.7 & 29.2 & 27.1 & 26.6 & 1.03 & 0.303 \\
\hline 13:0 & 1.6 & 1.1 & 2.9 & 0.8 & 1.35 & 0.695 \\
\hline $14: 0$ & 75.6 & 78.5 & 89.3 & 70.4 & 5.01 & 0.142 \\
\hline cis-9 14:1 & 6.3 & 5.3 & 6.6 & 5.5 & 1.25 & 0.828 \\
\hline $15: 0$ & 11.8 & 9.4 & 7.6 & 8.8 & 0.03 & 0.790 \\
\hline $16: 0$ & 177.3 & 173.1 & 150.0 & 165.5 & 8.19 & 0.195 \\
\hline cis7-16:1 & 4.5 & 4.0 & 3.4 & 3.7 & 0.36 & 0.278 \\
\hline cis9-16:1 & 6.4 & 4.7 & 3.3 & 4.5 & 1.47 & 0.551 \\
\hline $17: 0$ & 6.2 & 5.2 & 3.9 & 4.9 & 0.49 & 0.087 \\
\hline $17: 1$ & 2.2 & 2.5 & 1.5 & 1.9 & 0.55 & 0.663 \\
\hline 18:0 & 201.1 & 213.6 & 222.6 & 212.0 & 9.10 & 0.480 \\
\hline cis9-18:1 & $274.1^{\mathrm{bc}}$ & $265.3^{\mathrm{c}}$ & $311.4^{\mathrm{a}}$ & $303.5^{\mathrm{ab}}$ & 13.15 & 0.050 \\
\hline trans9-18:1 & 20.1 & 34.3 & 28.9 & 20.9 & 8.17 & 0.590 \\
\hline cis $9,12-18: 2$ & 28.5 & 37.0 & 30.0 & 30.6 & 4.26 & 0.483 \\
\hline trans $9,12-18: 2$ & 4.2 & 3.1 & 3.0 & 2.6 & 0.80 & 0.536 \\
\hline cis $6,9,12-18: 3$ & 6.2 & 1.8 & 2.4 & 3.0 & 1.24 & 0.157 \\
\hline cis $9,12,15-18: 3$ & 7.3 & 5.0 & 6.5 & 7.2 & 1.11 & 0.440 \\
\hline cis 9, trans $11-18: 2$ & $16.0^{\mathrm{a}}$ & $11.4^{\mathrm{b}}$ & $8.9^{\mathrm{b}}$ & $14.0^{\mathrm{a}}$ & 1.42 & 0.050 \\
\hline $20: 0$ & 7.8 & 7.7 & 4.9 & 5.8 & 1.62 & 0.537 \\
\hline $\operatorname{cis} 9,20: 1$ & 3.6 & 2.5 & 2.3 & 2.3 & 0.47 & 0.251 \\
\hline cis8,11,14-20:3 & 0.43 & 0.65 & 0.71 & 0.76 & 0.129 & 0.369 \\
\hline cis $5,8,11,14-20: 4$ & 1.7 & 1.4 & 1.8 & 1.5 & 0.32 & 0.844 \\
\hline Others ${ }^{c}$ & 11.4 & 11.8 & 10.2 & 10.3 & 1.93 & 0.847 \\
\hline Total trans & 40.4 & 48.7 & 40.9 & 37.5 & 9.51 & 0.856 \\
\hline MUFA $^{\mathrm{d}}$ & 322.4 & 323.3 & 362.1 & 348.0 & 12.93 & 0.074 \\
\hline PUFA $^{\mathrm{d}}$ & 65.2 & 61.0 & 53.8 & 60.9 & 6.01 & 0.500 \\
\hline $\mathrm{SFA}^{\mathrm{a}}$ & 612.4 & 615.7 & 584.2 & 591.1 & 14.48 & 0.248 \\
\hline PUFA/SFA & 0.11 & 0.10 & 0.09 & 0.11 & 0.010 & 0.412 \\
\hline$n-3^{e}$ & 7.3 & 5.2 & 6.6 & 8.0 & 1.10 & 0.412 \\
\hline$n-6^{1}$ & 41.1 & 44.0 & 37.9 & 38.5 & 5.32 & 0.791 \\
\hline$n-6: n-3$ & 5.6 & 8.5 & 5.7 & 4.8 & 2.63 & 0.188 \\
\hline
\end{tabular}

${ }^{\mathrm{a}-\mathrm{b}}$ Means within a row with different superscripts differ at $\mathrm{P} \leq 0.05$.

${ }^{\mathrm{c}}$ Others $=$ cis $9-14: 1+20: 0+20: 2+$ cis5,cis8,cis 11, cis 14, cis $17-20: 5+21: 0+22: 0+22: 2+$ cis 13, cis 16, cis $19-22: 3+$ cis4,cis7, cis10, cis13, $\operatorname{cis} 16, \operatorname{cis} 19-22: 6+23: 0+24: 0+24: 1$

${ }^{\mathrm{d}}$ MUFA = monounsaturated fatty acids; PUFA = polyunsaturated fatty acids; SFA = saturated fatty acids;

${ }^{\mathrm{e}}$ cis $9,12,15-18: 3+$ cis $5,8,11,14,17-20: 5+22: 5$.

f $c i s 9,12-18: 2+$ cis6,9,12-18:3 + cis $11,14-20: 2+$ cis8, 11,14-20:3 + cis5,8,11,14-20:4.

\section{DISCUSSION}

Treatment effects on dry matter digestibility were similar for all the diets. However, some nutrients presented variation, resulting in alteration in the TDN of the diets. Reduction effects on CP digestibility appeared to be related to the high indigestible nitrogen content in SCH (Souza et al. 2010). This feed has also some substances, caffeine and tannin that should be considered. These substances were previously reported harmful for nutrient utilization (Bressani et al.
1972). However, when animals were fed with concentrations lower than $1.2 \mathrm{~g} / \mathrm{kg}$ of caffeine and $7.5 \mathrm{~g} / \mathrm{kg}$ of tannin (on DM basis), no negative effects on the intake and nutrient utilization were observed (Cabezas 1976). It suggested that caffeine and tannin concentrations in the diets of the present experiment (Table 2) were low to be considered responsible for reducing protein digestibility. However, these substances added to other factors, such as high indigestible nitrogen, might have contributed to reduce the digestibility of protein. 
There are reports on lower NDF digestibility of feeding dry coffee hull to dairy cows (Rocha et al. 2006a; Rocha et al. 2006b). The high lignin content of SCH in the dry coffee hull could limit the digestibility of polysaccharides from cell wall in the rumen (Jung and Allen 1995). The inclusion of soybean oil in the three diets resulted about $7 \%$ increase in the ether extract digestibility when compared to the control diet. Indeed, lipids have a higher energy value, with a digestibility in the small intestine of ruminants ranging from 0.8 to $0.9 \mathrm{~kg} / \mathrm{kg}$ (Kozloski 2002), increasing the digestibility of ether extract. Thus, increase in the ether extract digestibility was caused by the intake of the dietary soybean oil. Soybean oil is rich in polyunsaturated fatty acids, which show better digestibility than saturated fatty acids (Palmquist and Mattos 2006). The increase of EE digestibility could explain the higher concentration of TDN in the diets with soybean oil, except for SOCH-150 diet. The reductions observed in the CP and NDF digestibility also could contribute to alter the TDN of the diets (Table 3 ). The inclusion of soybean oil certainly contributed to reduce the NDF and CP digestibilities (Table 3 ), as the fat had a protective effect against the digestion, resulting in a fat to protein inversion in the milk (Table 4).

Sticky coffee hull decreased milk lactose concentration. However, milk lactose content is barely influenced by the diet and changes in the concentration are generally uncommon because this carbohydrate is synthesized and secreted at the same rate as milk (Pulina et al. 2008). Even so, changes in lactose concentration have been reported in some studies with dairy cows; for example, decrease in milk lactose percentage was observed by Van Knegsel et al. (2007) in the cows fed lipogenic diets (high EE and NDF and low starch content) compared with the cows fed glucogenic diets. This reduction was attributed to the concomitant higher somatic cell counts observed in the cows fed lipogenic diets. Mastitis has been associated with mammary tissue damage, opening of tight junctions between the secretory cells and increase in the permeability of blood capillaries (Kitchen 1981), resulting in diffusion of ions down their respective concentration gradients and decreases milk lactose proportion to maintain a constant osmolarity in the milk (Kaufmann and Hagemeister 1987). However, differences in SCC were not observed in the current study (Table 4), which excluded this justification. In contrast, increases in the milk lactose concentration were observed in milk of cows from calving to 28 weeks of lactation (Petit and Côrtes 2010) fed flax-based diets. In these studies such observations were attributed to the effects of linolenic acid from flaxseed on glucose metabolism, which could improve gluconeogenesis rate (Mashek and Grummer 2003) and contributed to increase lactose concentration in the milk. Thus, possible changes in glucose metabolism promoted by the $\mathrm{SCH}$ might be related to decrease in lactose percentage in the milk. Therefore, the reduction in milk lactose must be more studied.

Milk urea nitrogen (MUN) is a useful parameter to predict the nutritional and reproductive stages of dairy cows (Grande et al. 2009). The average values of $\mathrm{N}$-urea in milk usually range from 12-18 $\mathrm{mg} / \mathrm{dl}$ (Santos et al. 2009). However, Oltner and Wiktorsson (1983) reported that MUN concentrations below $14 \mathrm{mg}$ of $\mathrm{N} / \mathrm{dl}$, as observed for the cows fed diets with the $\mathrm{SCH}$, indicated insufficient CP per unit of dietary energy. This effect could explained by the high indigestible nitrogen in SCH, represented by NDICP and ADICP (Table 1), and as consequence, its increase in the diets (Table 2). The supplementation of soybean oil might have contributed to the reduction in MUN in diets with $\mathrm{SCH}$, which could result a decrease in ammonia concentration in the rumen (Doreau and Ferlay 1995) and possibly influence the MUN concentration.

Other dietary feed ingredients used in the present study also contained polyphenols and flavonoids. Eguiés et al. (2012) described polyphenols in corn stalks, which were present in corn silage. Adom and Liu (2002) quantified the phenolic compounds in corn grain. Barbosa et al. (2006) described the total phenolic compounds in soybean meal, which supported the presence of polyphenols and flavonoids in the control and SBOIL diets, justifying the reducing power observed in these treatments (Table 4). According to Zhu et al. (2002), there is a relationship between the amount of total phenolic compounds and reducing power. Although soybean oil contained polyphenols and flavonoids, it was not responsible for increasing the reducing power observed in the milk. The increase was due to the inclusion of $\mathrm{SCH}$, since the increase was only observed when $\mathrm{SCH}$ was incorporated into the diets. This effect was evident when $15 \%$ of $\mathrm{SCH}$ was added to the diets, increasing to $75 \%$ the reducing power in the milk when compared to the CONT and SBOIL diets, and an increase to $50 \%$ when compared to SOCH- 
150. Thus, the $\mathrm{SCH}$, which was richer in the phenolic compounds than flavonoids (Table 1), could be considered responsible for the higher reducing power observed in the milk from the cows fed SCH (Table 4). The reducing power observed in the milk when cows were fed $150 \mathrm{~g} / \mathrm{kg}$ was slightly lower when compared with the milk of the cows fed $10 \%$ grape residue silage (Santos 2011). However, with respect to the transfer of these compounds in the milk, coffee hull was a good source of antioxidants to feed the cows. Furthermore, the fact that SCHS was a cheap byproduct (in coffee producing regions) that did not affect the productivity of the animals and also incorporated bioactive substances in the milk could not be neglected.

The total cholesterol and the LDL fraction were increased when cows were fed soybean oil. The LDL is the responsible for cholesterol transportation, justifying the similar pattern. This increase was likely due to the higher fatty acids intake. Grummer and Carroll (1991) also observed an increase in plasma cholesterol and its fractions, attributing this effect to the dietary fat. Dietary soybean oil has been reported to modify the fatty acid profile of the milk fat in the dairy cows where increased polyunsaturated fatty acids proportion was found (Jacobs et al. 2011). However, in the present study, there were no significant changes in overall fatty acid profile in the milk fat. The form of fat supply (unprotected) rendered polyunsaturated fatty acids to ruminal biohydrogenation, leading to similar fatty acids profile among the treatments. The final dietary fat concentration in the present study was considered low (NRC 2001). It could be possible that $30 \mathrm{~g}$ fat $/ \mathrm{kg}$ DM was insufficient to promote significant changes in the fatty acids profile in the milk fat.

\section{CONCLUSION}

Sticky coffee hull added up to $15 \%$ in dry matter basis in the diets of dairy cows did not alter milk production, weakly altered fatty acids profile in the milk fat and improved milk stability for possessing antioxidants that might retard its oxidation, at the same time improving its quality for human health.

\section{ACKNOWLEDGEMENTS}

The present study was funded by Conselho Nacional de Desenvolvimento Científico e Tecnológico - CNPq (DF, Brazil). The authors express their gratitude to the staff of Universidade Estadual de Maringá (PR, Brazil) for their contribution to the present study. We thank especially the "Associação de Criadores de Bovinos da Raça Holandesa" (Curitiba, PR, Brazil) for its assistance in milk analysis.

\section{REFERENCES}

Adom KK, Liu RH. Antioxidant activity of grains. $J$ Agric Food Chem. 2002; 50(21): 6182-6187.

Association of Official Analytical Chemists - AOAC. Official methods of analysis. 16.ed. Gaithersburg, M.P. 1998, 1141p.

Baggio J, Lima A, Mancini Filho J, Fett R. Identification of phenolic acids in coffee (Coffea arabica L.) dust and its antioxidant activity. Ital $J$ Food Sci. 2007; 19(2): 191-201.

Barbosa ACL, Hassimotto NMA, Lajolo FM, Genovese MI. Isoflavone content and profile and antioxidant activity of soy and soy products. Food Sci Tech. 2006; 26: 921-926.

Bressani R, Estrada E, Jarquin R. Pulpa y pergamino de café: I. composición química contenido de aminoácidos de la proteína de la pulpa. Turrialba. 1972; 22(3): 299-304.

Cabezas MT. Valor nutritivo de la pulpa de café para ganado de carne. Agric El Salv. 1976; 15(3): 25-39.

Côrtes C, Palin MF, Gagnon N, Benchaar C, Lacasse P, Petit HV. Mammary gene expression and activity of antioxidant enzymes and concentration of the mammalian lignan enterolactone in milk and plasma of dairy cows fed flax lignans and infused with flax oil in the abomasum. Br J Nutr. 2012; 108(8): 13901398.

Dai J, Mumper RJ. Plant phenolics: extraction, analysis and their antioxidant and anticancer properties. Molecules. 2010; 15(10): 7313-7352.

Doreau M, Ferlay A. Effect of dietary lipids on nitrogen metabolism in the rumen: a review. Livest Prod Sci. 1995; 43(2): 97-110.

Egüés I, Sanchez C, Mondragon I, Labidi J. Antioxidant activity of phenolic compounds obtained by autohydrolysis of corn residues. Ind Crop Prod. 2012; 36(1): 164-171.

Gagnon N, Côrtes C, Da Silva D, Kazama R, Benchaar C, Dos Santos G, et al. Ruminal metabolism of flaxseed (Linum usitatissimum) lignans to the mammalian lignan enterolactone and its concentration in ruminal fluid, plasma, urine and milk of dairy cows. Br J Nutr. 2009; 102(7): 1015-1023. 
Grande PA, Santos GTD, Ribeiro H, Damasceno JC, Alcalde CR, Barbosa OR, et al. Monitoring the nutritional and reproductive state of dairy cows through the presence of urea in milk. Braz Arch Biol Technol. 2009; 52: 249-258.

Grummer RR, Carroll DJ. Effects of dietary fat on metabolic disorders and reproductive performance of dairy cattle. J Anim Sci. 1991; 69(9): 3838-3852.

Han J, Britten M, St-Gelais D, Champagne CP, Fustier P, Salmieri S, et al. Polyphenolic compounds as functional ingredients in cheese. Food Chem. 2011; 124(4): 1589-1594.

ISO - International Organization for Standardization. Animal and vegetable fats and oils - Preparation of methyl esters of fatty acids. Method ISO 5509; 1978.

Jacobs AAA, Van Baal J, Smits MA, Taweel HZH, Hendriks WH, Van Vuuren AM, et al. Effects of feeding rapeseed oil, soybean oil, or linseed oil on stearoyl-CoA desaturase expression in the mammary gland of dairy cows. J Dairy Sci. 2011; 94(2): 874887.

Jung HG, Allen MS. Characteristics of plant cell walls affecting intake and digestibility of forages by ruminants. J Anim Sci. 1995; 73(9): 2774-2790.

Kaufmann W, Hagemeister H. Composition of milk. In: Gravert HO. Dairy Cattle Production. World Animal Science. C. Production System Approach. Amsterdam, The Netherlands: Elsevier Science Publishers; 1987. p.107-171.

Kitchen BJ. Review of the progress of dairy science: bovine mastitis: milk compositional changes and related diagnostic tests. J Dairy Res. 1981; 48(1): 167-188.

Korkina LG. Phenylpropanoids as naturally occurring antioxidants: from plant defense to human health. Cell Mol Biol. 2007; 53(1): 15-25.

Kozloski GV. Bioquímica dos ruminantes. Santa Maria: Editora UFSM; 2002.

Mashek DG, Grummer RR. Effects of long chain fatty acids on lipid and glucose metabolism in monolayer cultures of bovine hepatocytes. J Dairy Sci. 2003; 86(7): 2390-2396.

Matumoto-Pintro PT, Petit HV, Giroux HJ, Côrtes C, Gagnon N, Britten M. Effect of flaxseed lignans added to milk or fed to cows on oxidative degradation of dairy beverages enriched with polyunsaturated fatty acids. J Dairy Res. 2011; 78(1): 111-117.

Mertens DR. Gravimetric determination of amylasetreated neutral detergent fiber in feeds with refluxing in beakers or crucibles: collaborative study. J AOAC Int. 2002; 85(6): 1217-1240.

Murphy JJ, Connolly JF, Mcneill GP. Effects on milk fat composition and cow performance of feeding concentrates containing full fat rapeseed and maize distillers grains on grass-silage based diets. Livest Prod Sci. 1995; 44(1): 1-11.
National Research Council - NRC. Nutrients requirements of dairy cattle. 7.ed. Washington, D.C. 2001, 381p.

Oltner R, Wiktorsson H. Urea concentrations in milk and blood as influenced by feeding varying amounts of protein and energy to dairy cows. Livest Prod Sci. 1983; 10(5): 457-467.

Palmquist DL, Mattos WRS. Metabolismo de lipídeos. In: Berchielli TT. Nutrição de ruminantes, 1.ed. Jaboticabal: FUNEP; 2006. p.287-310.

Petit HV, Côrtes C. Milk production and composition, milk fatty acid profile, and blood composition of dairy cows fed whole or ground flaxseed in the first half of lactation. Anim Feed Sci Technol. 2010; 158(1): 36-43.

Poveda Parra AR, Moreira I, Furlan AC, Paiano D, Scherer C, De Oliveira Carvalho PL. Coffee hulls utilization in growing and finishing pigs feeding. $R$ Bras Zootec. 2008; 37(3): 433-442.

Pulina G, Nudda A, Battacone G. Nutrition and quality of goat's milk. In: Cannas A, Pulina G. Dairy goats feeding and nutrition. Bologna: CAB International; 2008. 1-30.

Rocha FC, Garcia R, Freitas AWDP, Souza ALD, Gobbi KF, Valadares Filho SDC, et al. Coffee hulls in diets of lactating dairy cows: intake, digestibility and milk yield and composition. $R$ Bras Zootec. 2006a; 35(5) 2163-2171.

Rocha FC, Garcia R, Freitas AWDP, Souza ALD, Valadares Filho SDC, Pereira OG, et al. Intake and digestibility of lactating dairy cows fed diets containing coffee hulls. $R$ Bras Zootec. 2006b; 35: 2154-2162.

Sánchez N, Miranda S, Vit P, Rodríguez-Malaver AJ. Propolis protects against oxidative stress in human saliva. J ApiProd ApiMed Sci. . 2010; 2(2): 72-76.

Santos GTD, Modesto EC, Souza NED, Ítavo LCV, Jobim CC, Kazama DCDS, et al. Replacement of corn silage with cassava foliage silage in the diet of lactating dairy cows: milk composition and economic evaluation. Braz Arch Biol Technol. 2009; 52(spe): 259-267.

Santos, NW. Silagem de resíduo de uva como fonte de antioxidante em dietas com óleo de soja para vacas leiteiras. Masters Dissertation [PhD Thesis]. Maringá, Brazil: Universidade Estadual de Maringá; 2011.

Shiota M, Konishi H, Tatsumi K. Oxidative stability of fish oil blended with butter. J Dairy Sci. 1999; 82(9): 1877-1881.

Silva DJ, Queiroz AC. Análise de Alimentos: métodos químicos e biológicos. Viçosa: Imprensa Universitária; 2002.

Singleton VL, Rossi JA. Colorimetry of total phenolics with phosphomolybdic-phosphotungstic acid reagents. Am J Enol Viti. 1965; 16: 144-158. 
Souza AL, Garcia R, Valadares SD, Rocha FC, Campos JMD, Cabral LD, et al. Effects of feeding coffee hulls on intake, digestibility and milk yield and composition of lactating dairy cows. $R$ Bras Zootec. 2005; 34(6): 2496-2504.

Souza ALD, Garcia R, Cabral LDS, Albuquerque Pereira ML, Diniz Valadares RF. Coffee hull in the diet of dairy heifers: nitrogen balance and microbial protein synthesis. R Bras Zootec. 2010; 39(5): 11411145.

Statistical Analysis System. SAS/STAT® (2003), User's guide: statistics, version 8.1. 4ed. Cary: SAS Institute, v. 2.

Teixeira RMA, Campos JMS, Valadares Filho SDC, Oliveira AS, Assis AJ, Santos Pina D. Intake, digestibility and performance of dairy heifers fed coffee hulls replacing of corn silage. $R$ Bras Zootec. 2007; 36(4): 968-977.

Valadares Filho SC, Machado PAS, Chizzotti ML, Magalhães KA, Júnior VRR, Capelle ER. Tabela Brasileira de Alimentos para Ruminantes. CBCAL 3.0 [homepage on the internet]. Viçosa: Universidade Federal de Viçosa; 2013 May [updated 2013 May; cited 2013 June 2]. Available from: http://cqbal.agropecuaria.ws/webcqbal/index.php.

Van Knegsel ATM, Van Den Brand H, Dijkstra J, Van Straalen WM, Jorritsma R, Tamminga S, et al. Effect of Glucogenic vs. Lipogenic Diets on Energy Balance, Blood Metabolites, and Reproduction in Primiparous and Multiparous Dairy Cows in Early Lactation. J Dairy Sci. 2007; 90(7): 3397-3409.
Vilela FG, Perez JRO, Teixeira JC, Reis ST. Uso da casca de café melosa em diferentes níveis na alimentação de novilhos confinados. Cienc Agrotec. 2001; 25(1): 198-205.

Voltolini TV, Santos GT, Zambom MA, Ribas NP, Müller EE, Damasceno JC, et al. Influência dos estádios de lactação sobre a contagem de células somáticas do leite de vaca da raça Holandesa e identificação de patógenos causadores de mastite no rebanho. Acta Sci Anim Sci. 2001; 23: 961-966.

Woisky RG, Salatino A. Analysis of propolis: some parameters and procedures for chemical quality control. J Apicult Res. 1998; 37(2): 99-105.

Yang J-H, Mau J-L, Ko P-T, Huang L-C. Antioxidant properties of fermented soybean broth. Food Chem. 2000; 71(2): 249-254.

Yen WJ, Wang BS, Chang LW, Duh PD. Antioxidant properties of roasted coffee residues. J Agric Food Chem. 2005; 53(7): 2658-2663.

Zhu QY, Hackman RM, Ensunsa JL, Holt RR, Keen CL. Antioxidative activities of oolong tea. J Agric Food Chem. 2002; 50(23): 6929-6934.

Received: June 04, 2013; Accepted: January 13, 2014. 